Universitas Muhammadiyah Bengkulu P-ISSN: 2599-1892

Vol. 1, No. 1, Januari 2018

\title{
Tinjauan Yuridis Terhadap Tenaga Kerja Wanita (Studi Kasus Pada Karyawan Wanita di Matahari Department Store kota Bengkulu)
}

\author{
THE JURIDICAL REVIEW ON WOMEN'S LABOR \\ (Case Study On Female Labor At Matahari Department Store Bengkulu City) \\ Mega Mawarti \\ Universitas Muhammadiyah Bengkulu, email: mega.mawarti@gmail.com
}

\begin{abstract}
ABSTRAK
Tenaga kerja (Labor) adalah penduduk yang sudah bekerja atau sedang, yang sedang mencari pekerjaan dan yang melaksanakan kegiatan lain seperti sekolah dan mengurus rumah tangga. Bagi pekerja/buruh perempuan yang belum berkeluarga masalah yang timbul berbeda dengan yang sudah berkeluarga yang sifatnya lebih subyektif. Berdasarkan beberapa permasalahan tenaga kerja wanita, maka dalam tulisan ini akan membahas bagaimana bentuk perjanjian kerja bagi Wanita Di Matahari Department Store Kota Bengkulu, bagaimana peranan Perusahaan terhadap pekerja Wanita di matahari Department Store menurut Undang-undang No.13 tahun 2003. Metode penelitian yang digunakan metode analisis Yuridis Normatif. Hasil penelitian menunjukkan bahwa Matahari Department store Kota Bengkulu, penerapan bentuk perjanjian kerja dan peranan perusahaan dalam memberikan kesejahteraan terhadap pekerja wanita tidak sepenuhnya sesuai dengan bentuk perjanjian yang di amanatkan oleh undang-undang No 13 Tahun 2003.
\end{abstract}

\section{Kata Kunci: Tenaga kerja wanita, kesejahteraan}

\begin{abstract}
Labor is a resident who works or is working, looking for job and is undertaking other activities such as schooling and housekeeping. For female labor who is unmarried, the problems that arise are different from those who have families that is more subjective. Based on several issues of female labors, this study discussed how the form of work agreement for female in Matahari Department Store of Bengkulu City is, and how the role of the Company to the female labors in Matahari Department Store is based on the Law No.13 year 2003. The research method used is Juridical Normative analysis method. The result of the research showed that in Matahari Department store of Bengkulu City, the implementation of work agreement form and the role of the company in providing welfare to female labors are not fully in accordance with the form of agreement mandated by law No. 13 of 2003.
\end{abstract}




\section{PENDAHULUAN}

Semakin meningkatnya jumlah kel ahiran, semakin menambah permasalah an bagi pemerintah untuk berfikir men gatasi bertambahnya penduduk ini. De ngan perkembangan yang pesat di sek tor perindustrian ini memberikan sediki solusi penyelesaian masalah, karena dalam suatu industri membutuhkan tenaga kerja yang kebanyakan di dominasi oleh pen duduk atau Warga Negara asli. Jadi te naga kerja yang dibutuhkan sangat banyak, sehingga hal tersebut memberikan suatu kesempatan kerja yang seluasluasnya bagi Warga Negara kita yang membutuhkan pekerjaan, yang pada dasarnya setiap manusia berhak untuk mempunyai pekerjaan, sepertiyang telah di jamin dengan peraturan perundangundangan sebagaimana diatur dalam Pasal 27 ayat (2) UUD 1945 yang ber bunyi "Tiaptiap warga negara berhak atas pekerja an dan penghidupan yang layak bagi kemanusiaan". Hak setiap warga negar a memiliki pekerjaan disini tidak lain a dalah guna mempertahankan hidup, at aupun untuk memenuhi kebutuhan hid up pribadinya maupun hidup keluargan ya yang semakin lama segala kebutuh an pokok dan kebutuhan lain yang se makin beraneka ragam dan mahal. Untuk memenuhi kebutuhan tersebut banyak pekerjaan yang menjadi pilihan untuk dilakukan salah satunya adalah sebagai buruh

Buruh adalah mereka yang bekerja pada usaha perorangan dan diberikan imbalan kerja secara harian maupun borongan sesuai dengan kesepakatan kedua belah pihak, baik lisan maupun tulisan, yang biasanya imbalan kerja tersebut diberikan secara harian. ${ }^{1}$

Yang dimaksud Tenagakerja (Labor) adalah penduduk yang sudah bekerja atau sedang, yang sedang mencari pekerjaan dan yang melaksanakan kegiatan lain seperti sekolah dan mengurus rumah tangga.

Ketenaga kerjaan dibagi menjadi Dua yaitu :

1. Tenaga Kerja tetap dan

2. Tenaga Kerja kontrak (Outsourcing) ${ }^{2}$

Sedangkan menurut UndangUndang No 13 Tahun 2003 tentang Ketenaga kerjaan, yang dimaksud dengan

\footnotetext{
${ }^{1}$ http://hujau.blogspot.com/2010/06/pengert ian-buruh-karyawan-dan-pegawai.html 11:50

${ }^{2}$ https://andresitohang.wordpress.com/abou t/perbedaan-karyawan-kontrak-outsourcingdengan-karyawan-tetap/ 11:26
} 
tenaga kerja adalah setiap orang yang mampu melakukan pekerjaan guna menghasilkan barang atau jasa baik untuk mmenuhi kebutuhannya sendiri maupun untuk masyarakat dengan menerima upah atau imbalan dalam bentuk lain. ${ }^{3}$

Upah adalah Hak
pekerja/buruh yang diterima dan
dinyatakan dalam bentuk uang sebagai
imbalan dari pengusaha atau pemberi
kerja kepada pekerja/buruh yang
ditetapkan dan dibayar menurut suatu
perjanjian kerja, kesepakatan, atau
peraturan
termaksud tunjangan bagi pekerja/buruh dan keluarganya atas suatu pekerjaan dan/atau jasa yang telah atau akan dilakukan. ${ }^{4}$

Istilah Outsourcing sebenarnya bersumber dari ketentuan yang terdapat dalam Pasal 64 Undang-Undang No 13 Tahun 2003 tentang ketenagakerjaan, yang menyatakan bahwa perusahaan dapat menyerahkan sebagian pelaksanaan pekerja kepada perusahaan lainnya melalui perjanjian pemborong pekerjaan

suka.ac.id/3977/1/BAB\%20I,\%20V \%20DAFTAR\% 20PUSTAKA.pdf;khoirul Umam, 10:56

${ }^{4}$ Undang-undang Ketenagakerjaan Pasal 1 angka 30 Tahun 2003 atau penyediaan jasa pekerja yang dibuat secara tertulis. $^{5}$

Pemerintah mempunyai kewajiban membina perlindungan kerja bagi tenag kerja Indonesia, dan tidak membedakan antara tenaga kerja laki-laki dan tenaga kerja wanita. Undang-undang No. 14 tahun 1969, pasal 2 menyebutkan bahwa : " Didalam menjalankan undang-undang ini serta peraturan pelaksaannya tidak boleh diadakan diskrininasi". Namun dalam kenyataan menunjukkan bahwa ada peraturan-peraturan atau ketentuan yang hanya diperuntukkan sifat kodrat wanita, yang pada saat tertentu mengalami haid, hamil, melahirkan dan sebagainya. Mengigat hal demikian pemerintah membina perlindungan kerja yang khusus bagi tenaga kerja wanita.

Secara umum hak dan kewajiban bagi tenaga kerja laki - laki maupun wanita adalah sama, seperti halnya pengaturan jam kerja / lembur, waktu kerja dan istirahat, peraturan tentang istirahat / cuti tahunan serta $d$. jaminan sosial, pengupahan dan sebagainya.

a. Pengaturan jam kerja / kerja lembur Didalam Undang - Undang nomor 1 tahun 1951 tentang

\footnotetext{
${ }^{5}$ Adrian sutedi" hukum perburuhan " "Bab 5 Outsourcing Tenaga Kerja dalam Perusahaan" hlm 217
} 
Tinjauan Yuridis Terhadap Tenaga Kerja Wanita

pernyataan berlakunya Undang Undang Nomor 12 tahun 1948 pasal 10 ayat 1 mengatakan : " Buruh tidak boleh menjalankan pekerjaan lebih dari 7 jam sehari dan 40 jam seminggu ". Ini berarti bahwa waktu kerja dibatasi hanya dalam jangka waktu 7 jam sehari dan 40 jam seminggu. Kenyataannya banyak perusahaan yang memperkerjakan pekerjaannya melebihi ketentuan tersebut diatas. Hal tersebut diperbolehkan asal ada izin dari Departemen Tenaga Kerja sebagaimana diatur dalam pasal 12 ayat 1 peraturan pemerintah No 4 tahun 1951 pasal II sub pasal 2 yang berbunyi sebagai berikut : Dengan izin dari kepala jawatan perburuhan atau yang ditunjuk olehnya, bagi perusahaan yang penting untuk penbangunan negara, majikan dapat mengadukan aturan waktu kerja yang menyompang dari pasal 10 ayat 1 , kalimat pertama ayat dua dan tiga Undang - Undang kerja tahun 1948. Didalam surat keputusan izin penyimpangan waktu kerja dan waktu istirahat dicantumkan syarat - syarat yang harus dipenuhi oleh pihak pengusaha. Pengaturan tentang kerja lembur tersebut diatur dalam keputusan Menteri Tenaga Kerja No.
KEP. 608/MEN/1989 tentang : " Pemberian izin penyimpangan waktu kerja dan waktu istirahat bagi perusahaan - perusahaan yang memperkerjakan pekerjaan 9 jam sehatri dan 54 jam seminggu ".

b. Waktu kerja dan waktu istirahat Pengaturan jam kerja diatur dalam Undang - Undang No. 1 tahun 1951, pasal 10 ayat dan ayat 3, yaitu : - Setelah buruh menjalankan pekerjaan selama 4 jam terus menerus diadakan waktu istirahat yang sedikitdikitnya $1 / 2$ jam lamanya diadakan waktu istirahat tidak termasuk waktu jam bekerja.

- Untuk tiap-tiap minggu harus diadakan sedikitnya satu hari istirahat. Hal ini dimaksudkan agar para pekerja setelah menjalankan pekerjaan didalam batas waktu tertentu setelah mendapat istirahat agar dapat segera menghadapi pekerjaan selanjutnya, dan diharapkan produktivitas kerja akan naik dengan terjaminnya keselamatan dan kesehatan kerja.

c. Pengaturan istirahat / cuti tahunan Bagi tenaga kerja yang sudah memiliki masa kerja 12 bulan berturutturut berhak untuk mendapat istirahat / cuti tahunan. Hal ini diatur dalam Undang-Undang No. 1 tahun 1951 
pasal 14 peraturan pemerintah No. 21/54 dan diperluas dengan surat keputusan menteri tenaga kerja dan Tranmigrasi No. 69/MEN/80 tentang perluasan lingkungan istirahat tahunan bagi buruh. Dalam pasal 14 disebutkan bahwa:

- Setelah waktu istirahat seperti tersebut dalam pasal 10 dan 13 buruh menjalankan pekerjaan untuk satu atau beberapa majikan dari suatu organisasi harus diberi izin untuk beristirahat sedikit-dikitnya dua minggu tiap-tiap tahun - Pemberian waktu istirahat tersebut disesuakan dengan jumlah hari masuk kerja selama 1 tahun.

d. Jaminan sosial dan Pangupahan Agar para pekerja dapat menjalankan pekerjaanya dengan semangat dan bergairah, masalah jaminan sosial dan pengupahan perlu diperlukan oleh perusahaan. Jaminan sosial yang dimaksud antara lain jaminan sakit ,hari tua, jaminan kaesehatan, jaminan perumahan, jaminan kematian dan sebangainya. Mengenai jaminan sosial ini sudah diatur secara normatip didalam perundangan, sehingga bagi perusahaan yang belum atau tidak memenuhi standard yang sudah ditetapkan dapat dikenakan sangsi.
Perihal perlindungan upah diatur dalam peraturan pemerintah No. 8 tahun 1981, antara lain mengatur tentang upah yang diterima oleh para pekerja apabila pekerja sakit, halangan atau kesusahan. Disamping itu diatur pula tentang larangan diskriminasi antara tenaga kerja laki-laki dan tenaga kerja wanita didalam hal menetapkan upah untuk pekerjaan yang sama nilainya.

Bagi pekerja/buruh perempuan yang belum berkeluarga masalah yang timbul berbeda dengan yang sudah berkeluarga yang sifatnya lebih subyektif, meski secara umum dari kondisi objektif tidak ada perbedaan-perbedaan. Perhatian yang benar bagi pemerintah dan masyarakat terhadap pekerja/buruh perempuan terlihat pada beberapa peraturanperaturan yang memberikan kelonggarankelonggaran maupun 5 larangan-larangan yang menyangkut kedirian seseorang perempuan secara umum seperti cuti hamil, kerja pada malam hari dan sebagainya. ${ }^{6}$

6 http://fh.unram.ac.id/wpcontent/uploads/2014/05/PERLINDUNGANHUKUM-TERHADAP-PEKERJA-PEREMPUAN-PADAMALAM-HARI-DI-MINIMARKET-ALFAMARTMATARAM.pdf 23 April 2015 13:26 
Wanita yang bekerja pada malam hari memiliki ancaman yang berbahaya untuk keselamatan. Karena wanita memiliki fisik yang lemah rawan nya untuk wanita yang bekerja pada malam hari. Karenaa rawannya ancaman bahaya banyak penjamberetan, pemerkosaan , dan pelecengan yang dialami wanita pada malam hari. Akan tetapi orang selalu beranggapan wanita yang pulang bekerja pada malam hari itu tidak baik. Karena dalam agama wanita memang dilarang keluar atau pulang pada malam hari.

Berdasarkan pengamatan penulis dilapangan Karyawan Wanita yang bekerja di Matahari Department Store berjumlah 300 Orang. Karyawan tersebut dibagi menjadi Dua siff, shif Siang dan shif Malam. Masing-masing shif berjumlah 150 Orang. $^{7}$

Dari Latar Belakang diatas adapun permasalahan yang ditemukan oleh penulis adalah sebagai beriku :

1. Bagaimana bentuk perjanjian kerja bagi Wanita Di Matahari Department Store Kota Bengkulu ?

2. Bagaimana peranan Perusahaan terhadap pekerja Wanita Di matahari Department Store menurut Undang-undang No.13 tahun 2003 ?

\footnotetext{
Wawancara "Karyawan Matahari Department Store" 30 Maret 2015
}

\section{METODE PENELITIAN}

Dalam menyusun artikel yang berjudul "TINJAUAN YURIDIS TERHADAP TENAGAKERJA WANITA (studi kasus pada karyawan wanita di Matahari Department Store kota Bengku/uy' ini penulis menggunakan metode penelitian metode analisis Yuridis Normatif adalah data tersebut dianalisis menurut Hukum dan peraturan Perundang-undangan yang berlaku saat ini. Dan langkah-langkah penelitian agar memperoleh hasil yang optimal. Metode dan langkah-langkah tersebut sebagai berikut :

\section{Sumber Data}

Dalam penelitian ini, sumber data yang digunakan adalah:

a. Data primer adalah data yang diperoleh langsung dari lokasi penelitian. Data Primer dari hasil penulisan ini adalah hasil wawancara dengan karyawan Wanita di Matahari Department Store dan bagian Sekretaris Manager di Matahari Department Store.

b. Semua data sekunder yang bersifat menjelaskan bahan hukum primer berupa pendapat para ahli sarjana 


\section{P-ISSN : 2599-1892}

Vol. 1, No. 1, Januari 2018

serta literatur-literatur yang relevan dengan objek penelitian.

Bahan-bahan hukum yang digunakan dalam penelitian ini antara lain:

1) Bahan Hukum Primer

Yaitu bahan hukum yang mengikat yang terdiri dari peraturan perundang-undangan yang berlaku atau ketentuanketentuan yang berlaku.

Sehubungan dengan itu maka bahan hukum primer yang digunakan adalah:

a) KUHPerdata

b) Undang-Undang No 13 Tahun 2003 tentang

Ketenagakerjaan.

c) Kepmen No 102 tahun 2004 tentang Waktu lembur

2) Bahan Hukum Sekunder

Bahan hukum sekunder
yang digunakan untuk
mendukung bahan hukum primer,
diantaranya yang berasal dari
karya para sarjana, jurnal, data
yang diperoleh dari instansi, serta
buku-buku kepustakaan yang
dapat dijadikan referensi yang
dapat menunjang penelitian ini.

3) Bahan Hukum Tersier

Yaitu bahan hukum yang mengandung bahan hukum sekunder yang berasal dari kamus.

Metode pengumpulan data dalam penelitian ini adalah dengan studi pustaka dan studi lapangan. Studi lapangan dengan wawancara. Wawancara dilakukan dengan narasumber dalam mendapatkan data dan kebenaran data yang berkaitan dengan permasalahan.

Dengan demikian untuk mencari data dalam penelitian ini dengan cara :

a. Studi Pustaka

Penelitian ini dilakukan melalui penelusuran berbagai peraturan perundang-undangan, buku-buku, tulisan ilmiah dan makalah yang berkaitan dengan masalah yang diteliti.

b. Penelitian Lapangan

Metode penelitian yang dilakukan peneliti dilapangan yang diamati oleh peneliti secara langsung untuk mendapatkan bahan-bahan atas informasi mengenai masalah-masalah yang diteliti yang dilakukan dengan cara wawancara yaitu peneliti memperoleh informasi secara langsung dengan mempergunakan metode tanya jawab.

c. Data yang dicari

Data-data yang dikumpulkan dari penelitian ini terdiri dari data-data .

d. Lokasi Penelitian 
1. Matahari Departmen Store Kota Bengkulu

2. Dinas ketenagakerjaan dan Transmigrasi Kota Bengkulu

3. Dinas ketenagakerjaan dan Olahraga Kota Bengkulu

Data yang diperoleh dianalisis dan diolah dengan 3 (tiga) cara yaitu :

Pertama-tama data yang dikumpulkan dalam pencarian data itu disusun dalam satu sistem (disistematiris), kemudian data yang telah tersusun dalam satu system itu dijelaskan dalam satu evaluasi, selanjutnya berdasarkan penjelasan dan evaluasi dibuat kesimpulan. ${ }^{8}$

Kebenaran Kualitarif kebenaran dalam arti kesesuaian dengan ukuran yang menatapkan persyaratan kualitas tertentu yang harus dipenuhi hal ini disebabkan karena kebenaran berdasarkan ketentuan hukum positif kebanyakan ditentukan berdasarkan ketentuan hukum positif kebanyakan ditentukan berdasarkan persyaratan kualitas. $^{9}$

\section{PEMBAHASAN}

1. Bentuk perjanjian kerja bagi Wanita Di Matahari Department Store Kota Bengkulu ?

Berdasarkan wawancara penulis dengan salah satu staf bagian pengawasan di Dinas tenagakerja dan Olahraga Kota Bengkulu Muhamad Khisfan isi dari Kontrak kerja adalah sebagai berikut :

1. Nama, alamat Perusahaan yang memberi Kerja

2. Nama, Alamat Pekerja/buruh

3. Jenis Pekerjaan yang dilakukan

4. Besarnya Upah / imbalan yang diperoleh

Adapun syarat sah suatu perjanjian menurut KUHPerdata Pasal 1320 adalah sebagai berikut :

1. Adanya kesepakatan antara para pihak ( tidak ada dwangpaksaan, dwalingpenyesatan/kekhilafan atau bedrog-penipuan)

2. Pihak-pihak yang bersangkutan mempunyai kemampuan atau kecakapan untuk (bertindak) melakukan perbuatan hukum 
(cakap usia dan tidak dibawah perwalian/pengampuan).

3. Ada (objek) pekerjaan yang diperjanjikan; dan

4. (Causa) pekerjaan yang diperjanjikan tidak bertentangan dengan ketertiban umum, kesusilaan, dan peraturan perundang-undangan yang berlaku (Pasal 52 ayat (1) undang-undang

Ketenagakerjaan).$^{10}$

Adapun bentuk - bentuk perjanjian kerja ialah :

a. Perjanjian kerja secara Lisan

b. Perjanjian kerja secara tulisan

Hubungan kerja yang terjadi antara karyawan yang perusahaan karena adanya kesepakatan antara perusahaan dan karyawan. Perjanjian kerja bisa dibuat secara tertulis dan secara lisan. Perjanjian kerja yang dipersyaratkan secara tertulis dilaksanakan sesuai dengan peraturan peundang-undangan yang berlaku saat ini, sedangkan perjanjian kerja yang secara lisan bisa dilaksanakan secara kesepakatan antara kedua belah pihak. Misalkan , antara pekerja dan majikan yang bekerja di sektor rumah tangga atau yang bukan berada dibawah pimpinan perusahaan.

Undang-undang No 13 Tahun 2003 tentang ketenagakerjaan yang mengatur perjanjian kerja. Disebutkan dalam undang-undang tersebut perjanjian kerja dibagi menjadi tiga yaitu sebagai berikut :

a. Perjanjian kerja untuk waktu tertentu

b. Perjanjian kerja untuk waktu tidak tertentu

c. Perjanjian kerja borongan / harian

Perjanjian kerja waktu tertentu di atur dalam pasal 8 Undangundang No 13 Tahun 2003 tentang ketenagakerjaan, adapun isi dari pasal 8 Undang-undang ketenagakerjaan adalah sebagai berikut :

1. Perjanjian kerja untuk waktu tertentu didasarkan atas jangka waktu ; atau selesainya pekerjaan tertentu.

2. Perjanjian kerja untuk waktu tertentu tidak dapan 
mensyaratkan adanya masa percobaan.

3. Perjanjian kerja untuk waktu tertentu dapat diperpanjang atau diperbaharui.

4. Perjanjian kerja untuk waktu tertentu yang didasarkan atas jangka waktu tertentu dapat diadakan untuk paling lama 2 (dua) tahun dan hanya boleh diperpanjang 1 (satu) kali untuk jangka waktu paling lama 1 (satu) tahun.

5. Selama karyawan terikat dalam perjanjian kerja untuk waktu tertentu tidak dihitung sebagai masa kerja karyawan.

Perjanjian kerja waktu tertentu (PKWT) wajib dicatatkan oleh pengusaha kepada instansi yang bertanggungjawab dibidang ketenagakerjaan di Kabupaten / Kota . Yang ditanda tangani oleh Pekerja dan Pihak Pengusaha .

Sedangkan menurut Pasal 9 Perjanjian Kerja waktu tidak tertentu sebagai berikut :

1. Perjanjian kerja untuk waktu tidak tertentu dapat mensyaratakan masa percobaan kerja paling lama 3 (tiga) bulan.
2. Masa percobaan dihitung sebagai masa kerja karyawan

3. Dalam masa percobaan kerja sebagaimana dimaksud pada ayat (1) dilarang membayar upah dibawah upah minimum yang berlaku.

Perjanjian kerja di Matahari Department Store itu bisa di sebut perjanjian kerja waktu tertentu dan Perjanjian kerja waktu tidak tertentu. Sesuai dengan peraturan dari perusahaan yang diketahui oleh Dinas Ketenagakerjaan .

Perjanjian kerja harian / borongan adalah perjanjian kerja yang dilakukan antara kedua belah pihak guna mendapatkan upah yang sesuai dengan apa yang telah dia lakukan. Perjanjian kerja harian / borongan dilakukan secara lisan. Perjanjian kerja ini tidak mengikat kontrak yang sah. Perjanjian kerja harian / borongan dilakukan sesuai dengan pemberi kerja yang member pekerjaan . pekerjaan itu kapan dan sampai kapan selesainya

Isi dari perjanjian kerja adalah aturan - aturan yang harus disetujui dan disepakati oleh 
karyawan . Aturan - aturan tesebut harus disepakati dan disetujui oleh karyawan. Sedangkan Menurut Undang - Undang No 13 Tahun 2003 menjelaskan yang dimaksud dengan perusahaan ialah sebagai berikut ;

" Peraturan yang dibuat secara tertulis oleh pihak pengusaha yang memuat syarat - syarat kerja dan tata tertib perusahaan ".

Adapun yang termaksud poin poin dalam kontrak Kerja ialah sebagai berikut :

Bahwa dari hasil penelitian penulis dilapangan Kontrak kerja yang disepakati antara perusahaan dan pekerja / buruh itu manjadi rahasia perusahaan untuk keamanan perusahaan dan isi dari perjanjian Kerja antara Wanita dan laki-laki tidak berbeda . jadi tidak ada diskriminasi antara Wanita dan laki-laki.

Pekerja / buruh menerima hasil dari apa yang sudah ia lakukan melalui jasa, apa yang dia terima harus sesuai dengan apa yang telah dia lakukan . adapun upah harian yang sesuai dengan dia lakukan dan upah bulanan dari perusahaan. Upah / gaji yang diterima oleh karyawan harus tetap waktu .

Upah yang sering kita dengar dalam masyrakat ialah upah harian yang telah dia kerjakan . sedangkan upah dalam perusahaan di sebut dengan gaji pokok dari perusahaan untuk karyawan .

Upah Minimun Sektor Provinsi (UMSP) Bengkulu tahun 2015 menjadi sebesar Rp 1.545.000- (Satu Juta Lima Ratus Empat Puluh Lima Ribu Rupiah) perbulan . Upah Minimun Sektor Provinsi dicatat di Keputusan Gubernur Bengkulu Nomor w.174.XIX Tahun 2015 .

Sedangkan Upah Minimun yang diperoleh oleh karyawan di Matahari Department Store Kota Bengkulu sebesar Rp 1.500.000,-(Satu Juta Lima Ratus Ribu Rupiah).

Undang-undang No 13 tahun 2003 tentang ketenagakerjaan meneyebutkan Upah adalah hak pekerja / buruh yang diterima 
dan dinyatakan dalam bentuk uang sebagai imbalan dari pengusaha atau pemberi kerja kepada pekerja / buruh yang ditetapkan dan dibayarkan menurut suatu perjanjian kerja , kesepakatan , atau peraturan perundang - undangan , termaksud tunjangan bagi pekerja / buruh dan keluarganya atas suatu pekerja dan/ atau jasa yang telah atau akan dilakukan .

Menurut Pasal 88 Undangundang No 13 tahun 2003 adapun kebijakan yang melindungi buruh / pekerja sebagaimana yang dimaksud dalam ayat (2) ialah sebagai berikut :

a. Upah Minimun

b. Upah kerja lembur

c. Upah tidak masuk kerja karena berhalangan

d. Upah tidak masuk kerja karena melakukan kegiatan diluar pekerjaannya

e. Upah tidak menjalankan hak waktu istirahat kerja

f. Bentuk dan cara pembayaran upah g. Denda dan potongan upah

h. Hal - hal yang dapat diperhitungkan dengan upah

i. Struktur dan skala pengupahan yang proporsional

j. Upah untuk membayar pesangon dan

k. Upah untuk perhitungan pajak penghasilan

Gaji yang diterima oleh pekerja / buruh belum sesuai dengan kebutuhan hidup sehari - hari karena kebutuhan hidup perekonomian buruh sangantalah besar . terutama bagi buruh yang berkeluarga dan meiliki anak .

Gaji sebesar Rp 1.500.000,yang sudah termaksud UMP Kota Bengkulu sangatlah kecil dan belum sejahtera karena uang $\operatorname{Rp} 1.500 .000$,- itu untuk hidup 1 bulan , sedangkan kehidupan sehari - hari karyawan yang tinggal dikontrakan (Kost) itu tidak cukup. Untuk makan, bayar kontrakan perbulan, biaya 
trasportasi bahkan ada hal - hal yang tidak terduga.

\section{Peranan Perusahaan terhadap pekerja Wanita Di matahari Department Store Kota Bengkulu}

Setiap orang yang bekerja baik Wanita maupun Laki - laik berhak memiliki hak yang sama di perusahaan - kalau hak wanita dan laki - laki dibedakan itu namanya diskriminasi . Setiap manusia dihadapan hokum sama tidak dibeda - bedakan. Akan tetapi dalam suatu perusahaan ada Hak untuk cuti yang diperoleh oleh wanita menurut Undang - Undang No 13 tahun 2003.

\begin{abstract}
Dari hasil wawancara yang dilakukan oleh peneliti kepada salah satu karyawan wanita yang bekerja di Matahari Department Store menyebutkan bahwa :
\end{abstract}

"Di Matahari Department Store Kota Bengkulu tempat penitipan anak tidak ada. Tapi perusahaan memperbolehkan karyawan untuk pulang menyusui anak atau melakukan Pompa susu . di Matahri Department store juga tidak terlaksanakannya hari libur untuk wanita padda awal mandapatkan haid. ${ }^{\prime 11}$

Setiap pekerja yang melakukan Hak Untuk Cuti baik itu mingguan, tahunan, dan istirahat panjang , melaksanakan ibadah haji , melahirkan , keguguran berhak memperoleh upah penuh .

Dari hasil penelitian dilapangan bahwa Karyawan yang bekerja di Matahari Department store peraturan perasahaan cumin dilaksanakan 2 Shift , shift pagi dan shift siang. Apabila bekerja melebihi batas waktu kerja yang telah ditentukan tidak dibayar uang upah lembur dan itu termaksud dalam gaji Pokok dari perusahaan .

\section{PENUTUP}

\section{Kesimpulan}

Berdasarkan hasil penelitian di atas dengan ini penulis mengambil kesimpulan sebagai berikut :

1. Bahwa di Matahari Department store Kota Bengkulu, penerapan bentuk perjanjian kerja tidak sepenuhnya sesuai dengan bentuk perjanjian yang di amanatkan oleh undang-undang No 13 Tahun 2003. Hal ini dibuktikan dengan

11 Wawancara terhadap karyawan wanita Okta 20 April 2015 
temuan penulis bahwa hak wanita yang dalam keadaan haid tidak diberikan cuti haid, dan keselamatan pekerja wanita kurang diperhatikan. Hal ini bertentangan juga dengan teori Keynes dimana kesejahteraan karyawan/pekerja merupakan fikus yang menjadi anjuran teori ini. Hal ini dpat dilihat dari tidak disediakannya transportasi bagi pekerja wanita.

2. Dari hasilan penelitian penulis, bahwa peranan perusahaan dalam memberikan kesejahteraan terhadap pekerja wanita belum sepenuhnya mengikut amanah menurut Undang-undang nomor 13 tahun 2003. Hal ini dibuktikan dengan temuan penulis bahwa upah lembur dihari biasa tidak diberikan oleh perusahaan tidak menyediakan tempat untuk pekerja yang sedang menyusui serta keselamatan pekerja yang masih diaturkan. Temuan ini juga bertentangan dengan Teori Keynes dimana kesejahteraan karyawan/pekerja merupakan fokus menjadi anjuran teori ini dan teori Pembangunan menjelaskan pekerja/buruh harus memiliki keselamatan kerja jati diri sendiri dan pantas untuk menghargai diri sendiri dan merasa layak dihargai. Sehingga kesejahteraan pekerja di Matahari Department Store Kota bengkulu belum diperoleh sepenuhnya oleh pekerja wanita.

\section{Saran}

1. Perlu standar pengawasan yang akurat bagi Disnaker dalam mengawasi perusahaan-perusahaan yang memperkerjakan tenaga kerja Wanita.

2. Perlu sosialisasi yang efektif dan berkelanjutan kepada pengusaha dan pekerja agar masing - masing pihak dapat mengetahui hak dan kewajiban.

\section{DAFTAR PUSTAKA}

Adrian sutedi" hukum perburuhan " "Bab 5 Outsourcing Tenaga Kerja dalam Perusahaan" hlm 217

F Sugeng Istanto, 2007, penelitian hukum,CV.Ganda, Yogyakarta hal 26 http://hujau.blogspot.com/2010/06/pengertianburuh-karyawan-dan-pegawai.html $11: 50$

https://andresitohang.wordpress.com/about/perbe daan-karyawan-kontrak-outsourcingdengan-karyawan-tetap/ 11:26

http://digilib.uinsuka.ac.id/3977/1/BAB $\% 20 \mathrm{I}, \% 20 \mathrm{~V}, \% 2$ ODAFTAR\%20PUSTAKA.pdf; khoirul Umam, 10:56

http://fh.unram.ac.id/wpcontent/uploads/2014/05/PERLINDUNG AN-HUKUM-TERHADAP-PEKERJAPEREMPUAN-PADA-MALAM-HARI-DI- 


\section{P-ISSN : 2599-1892}

Vol. 1, No. 1, Januari 2018

MINIMARKET-ALFAMART-MATARAM.pdf 23 April 2015 13:26

KUHPerdata pasal 1320

Undang-undang Ketenagakerjaan Pasal 1 angka 30 Tahun 2003

Wawancara terhadap karyawan wanita Okta 20 April 2015

Wawancara "Karyawan Matahari Department Store" 30 Maret 2015 